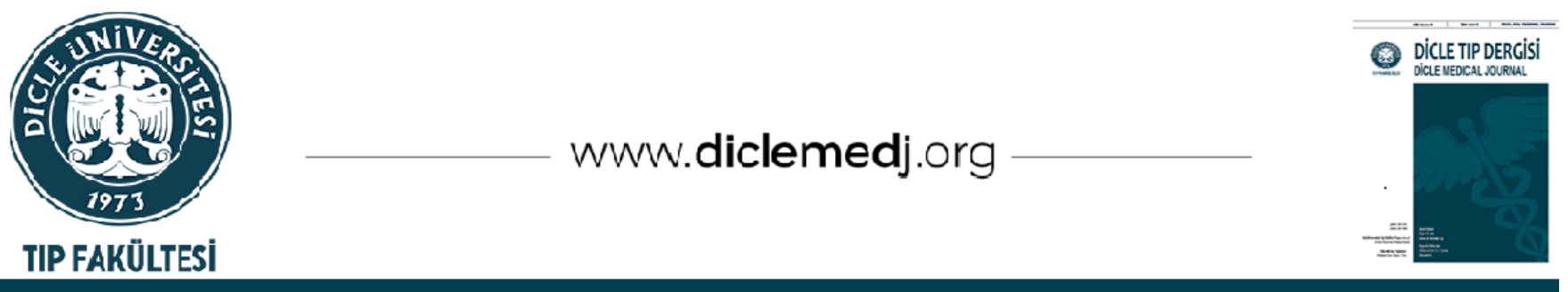

Özgün Araştırma / Original Article

\title{
Küçük ve Dev Ensefalosellerin Etiyolojik Faktörler ve Peroperatif Süreç Açısından Karşılaştırılması
}

\author{
Pınar Aydın Öztürk $D_{1}$, Abdurrahman Arpa $D_{1}$, Muhammet Asena ${ }^{2}$ \\ 1 Sağlık Bilimleri Üniversitesi Gazi Yaşargil Sağlık Uygulama ve Araştırma Merkezi, Nöroşirurji Bölümü, Diyarbakır, Türkiye \\ 2 Sağlık Bilimleri Üniversitesi Gazi Yaşargil Sağlık Uygulama ve Araştırma Merkezi, Pediatri Bölümü, Diyarbakır, Türkiye \\ Geliş: 18.02.2021; Revizyon: 26.03.2021; Kabul Tarihi: 27.03.2021
}

Öz

Amaç: Ensefaloseller konjenital nöral tüp defeklerinden olup beyin ve/veya meninkslerin kafatasındaki bir defektten dışarı çıkması ile karakterizedir. Ensefalosel kesesinin kafadan büyük olduğu olgular 'dev ensefaloseller' olarak adlandırılırlar. 'Dev ensefalosel'lerin yönetimi küçük keseli ensefalosellerden oldukça farklıdır. Bu çalışma ile küçük ve dev ensefaloseller karşılaştırılarak etiyolojik ve peroperatif yönetim açısından karşılaştırılmıștır.

Yöntemler: Hastanemizde yenidoğan döneminde opere edilen ensefaloseller boyutlarına göre iki gruba ayrılarak ayrı ayrı ve karşılaştırılmalı olarak değerlendirilmiştir.

Bulgular: Çalışmaya ensefalosel nedeniyle opere edilen 32 hasta dahil edilmiştir. Hastaların $\% 62,5^{\prime} \mathrm{i}$ kız bebek, \%37,5'i erkek bebektir. Hastaların \%15,6'sında 'dev ensefalosel' mevcuttu. Hastaların \%53,1'inde kese içerisine herniye olmuş nöral doku mevcuttu. Hastaların \%21,9'unda ek anomali mevcuttu. Hastaların \%65,6'sında doğumda veya bir yıllık takip süresinde şant takılmasını gerektirecek ventriküler dilatasyon saptanmıştır. Kese boyut ortalaması $74.6 \pm 110.3 \mathrm{~cm}^{2}$ olarak saptanmıştır. Kese boyutu arttıkça defisit gelişme riski daha yüksek bulunmuştur ( $p=0.023)$.

Sonuç: Ensefaloseller peroperatif süreci multidisipliner bir anlayışla iyi yönetilmesi gereken bir hasta grubudur. Her ne kadar 'dev ensefaloseller'in postoperatif süreci diğer ensefalosellerle aynı olsa da preoperatif hazırlı̆̆ın dikkatli yapılması, anestezi ve cerrahi ekibin koordine çalışması diğer ensefalosellere göre yüksek olan peroperatif komplikasyon riskini azaltacaktır.

Anahtar kelimeler: Ensefalosel, dev ensefalosel, nöral tüp defekti

DOI: 10.5798/dicletip.944382

Yazışma Adresi / Correspondence: Pınar Aydın Öztürk, Nöroşirurji Bölümü, Sağlık Bilimleri Üniversitesi Gazi Yaşargil Sağlık Uygulama ve Araştırma Merkezi, Diyarbakır, Türkiye Üçkuyular / Kayapınar / Diyarbakır, Türkiye e-mail: aydinpinar12@gmail.com 


\title{
Comparison of Small and Giant Encephaloceles in Terms of Etiological Factors and Peroperative Process
}

\begin{abstract}
Objective: Encephaloceles are congenital neural tube defects and are characterized by the herniated of the brain and / or meninges through a defect in the skull. Cases where the encephalocele sac is larger than the head are called 'giant encephaloceles'. The management of 'giant encephaloceles' is quite different from small encephaloceles. In this study, small and 'giant encephaloceles' were compared in terms of etiological and peroperative management.

Methods: The encephaloceles operated in the neonatal period in our hospital were divided into two groups according to their size and evaluated separately and comparatively.

Results: 32 patients who were operated for encephalocele were included in the study. $62.5 \%$ of the patients are females and $37.5 \%$ are males. $15.6 \%$ of the patients had 'giant encephalocele'. $53.1 \%$ of the patients had neural tissue herniated into the sac. Extra-cranial anomaly was present in $21.9 \%$ of the patients. Ventricular dilatation requiring shunt insertion was found in $65.6 \%$ of the patients at birth or during a one-year follow-up period. Mean size of the sac was found to be $74.6 \pm 110.3 \mathrm{~cm}^{2}$. Sac size as it increases, enhanced the risk of developing deficits $(\mathrm{p}=0.023)$.

Conclusion: Encephaloceles are a group of patients whose peroperative process should be managed well with a multidisciplinary approach. Although the postoperative process of "giant encephaloceles" is the same as other encephaloceles, careful preoperative preparation and coordinated work of the anesthesia and surgical team will reduce the risk of peroperative complications, which is higher than other encephaloceles.
\end{abstract}

Keywords: Encephalocele, giant encephalocele, neural tube defect.

\section{GíRiş}

Ensefaloseller konjenital nöral tüp defeklerinden olup beyin ve/veya meninkslerin kafatasındaki bir defektten dışarı çıkması ile karakterizedir1,2. Ensefalosel kesesi siklıkla normal ciltle kaplıdır 3 . Herniye doku genellikle fibrotik, gliotik bir doku olup bazen normal beyin dokusu da olabilmektedir4. Epidemiyolojik insidansına bakıldığında 0.85.6/10.000 (canlı doğum) oranında görülür5. Ensefaloseller genellikle sporadik ${ }^{6}$ olsa da nadiren sendromlara eşlik eden bir bulgu olarak da görülebilirler (en sık Meckel-Gruber Sendromu $)^{7,8}$.

Ensefalosel kesesinin kafadan büyük olduğu olgular 'dev ensefaloseller' olarak adlandırılırlar. 'Dev ensefalosel'lerin tedavi yönetimi, peroperatif süreçteki yönetim küçük keseli ensefalosellerden oldukça farklıdır9 ${ }^{9}$

Ensefaloseller preoperatif hazırlı ve peroperatif süreçteki zorlukları, eşlik eden anomaliler yönüyle iyi yönetilmesi gereken bir konjenital hastalık grubudur. Bu çalışma ile hastanemizde opere edilen ensefalosellerin retrospektif olarak değerlendirilmesi ve küçük keseli ensefalosellerin tedavi yönetim sürecindeki zorlukları ile 'dev ensefaloseller' ile karşılaştırılması amaçlanmıştır.

\section{YÖNTEMLER}

Çalışma için Sağlık Bilimleri Üniversitesi Gazi Yaşargil Eğitim Araştırma Hastanesi girişimsel olmayan klinik araştırmalar etik kurulundan 14.02.2020 tarih 402 sayı numarası ile onay alınmıştır. Tüm hastalar için bilgilendirilmiş yazılı onam alınarak Helsinki Deklarasyonu prensiplerine uyulmuştur.

Çalışmaya 2017-2021 yılları arasında hastanemizde posterior kranial ensefalosel nedeniyle opere edilen 32 hasta dahil edilmiştir. Çalışma için hastaların cinsiyet, nörolojik durum, ek patoloji olup olmadığı, kese boyutu, hidrosefali eşlik edip etmediği, anne yaşı, ebeveynlerde akrabalık öyküsü ve mortalite dahil edilmiştir. Görüntülemelerine ve verilerine ulaşılamayan, bir ylllk takibi 
olmayan (mortalite ile sonuçlananlar dışında) hastalar çalışma dışı bırakılmıștır.

Hastalara preoperatif dönemde kranial manyetik rezonans görüntüleme (MRG) yapılarak kese içeriği, anjiografi ile sinüs ilişkisi değerlenlendirilmiştir. Klinik durumu veya kese boyutu nedeniyle MRG çekimi yapılamayan hastalara beyin bilgisayarlı tomografi çekimi yapılmıștır. Hastaların hiçbirinde kesenin sinüs ile ilişkisi saptanmamıştır.

Hastaların tamamı yenidoğan döneminde opere edilmiştir. Hastalar hidrosefali açısından bir yıllık takipleri ile değerlendirilmiştir. Mortalite açısından peroperatif dönemdeki (yenidoğan dönemi) mortalitesi ile çalışmaya dahil edilmiştir.

\section{İstatistiksel Analiz}

Veriler ortalama değer, sayı ve yüzde, minimum ve maksimum olarak değerlendirildi. Veriler arasındaki korelasyonu değerlendirmek için iki değişkenli korelasyon (Pearson's R, Spearmen korelasyon, One-Way ANOVA) kullanıldı. Normal dağılıma uymayan bağımsız verilerin analizinde Mann Whitney U testi kullanıldı. Kategorik veriler için ki-kare testi yapıldı. Analiz için SPSS for Windows (sürüm 20.0) kullanıldı. p değeri 0.05 'ten küçük olması anlamlı olarak kabul edildi.

\section{SONUÇLAR}

Çalışmaya hastanemiz yenidoğan servisinde takip edilen ve aynı cerrahi ekip tarafından opere edilen 32 hasta dahil edilmiştir.

Hastaların \%62,5'i kız bebek, \%37,5'i erkek bebektir. 'Dev ensefaloseli' olan hastaların $\% 60$ 'ı erkek bebekti. Hastaların \%87,5'inde ekstremitelerde nörolojik defisit yoktu ancak $\% 6,25$ 'i paraplejik, \%6,25'i ise quadriparetikti. Plejik olanların nörolojik tablosu eşlik eden spina bifidaya sekonderdi (Tablo 1).

Bir olguda kese vertex yerleşimli iken (Fig 1) diğer olguların tamamında kese occipital/occipitoservikal bölge yerleşimliydi (Fig 2). Hastalarda en küçük kese boyutu $2 \mathrm{~cm}^{2}$ iken, en büyük kese boyutu $400 \mathrm{~cm}^{2}$ idi. Kese boyut ortalaması $74.6 \pm 110.3 \mathrm{~cm}^{2}$ olarak saptanmıştır. Kız bebeklerin kese boyut ortalaması erkek bebekler kese boyut ortalamasından küçük olsa da $\left(60.0 / 90.5 \mathrm{~cm}^{2}\right)$ istatistiksel olarak anlamlı bulunmamıştır $(\mathrm{p}=$ 0.535). Hastaların \%15,6'sında 'dev ensefalosel' mevcuttu (Fig 3). Kız bebeklerin \%10'unda, erkek bebeklerin \%25'inde 'dev ensefalosel' saptanmış olup istatistiksel olarak anlamlı bulunmamıştır ( $\mathrm{p}=$ 0.261). Hastaların \%53,1'inde kese içerisine herniye olmuş nöral doku mevcuttu (Tip III Chiari) (Fig 4). Nörolojik muayenesi normal olan hastaların kese boyutu ortalaması $62.0 \pm 22.5$, paretik olanların kese boyutu ortalaması $275.0 \pm 35.4 \mathrm{~cm}^{2}$, plejik olanların kese boyut ortalaması $50 \pm 14.1 \mathrm{~cm}^{2}$ olarak tespit edilmiştir. Plejik olanların defisit etiyolojisi eşlik eden spina bifida iken, parezinin kese boyutu ile ilişkisi istatistiksel olarak anlamlı saptanmıştır $(\mathrm{p}=0.023)$. Bu durumun kesesi büyük olanlarda daha fazla nöral doku olması ile ilişkili olduğu düșünülmüștür.

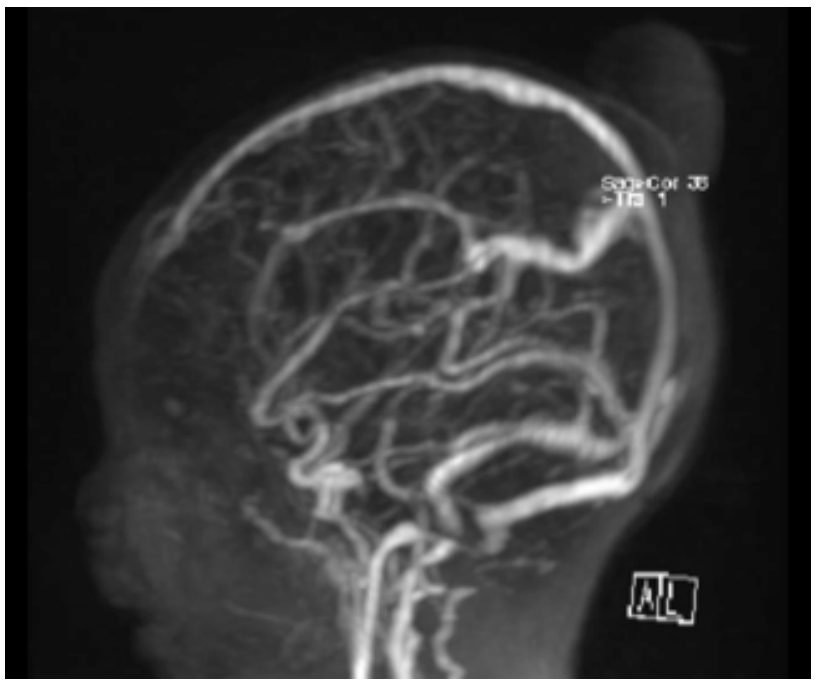

Resim 1. Verteks yerleşimli ensefalosel olgusunun kranial MR ve MR anjiografi görüntüsü. Venöz sinüs ilişkisi olmadığı görülmekte. 


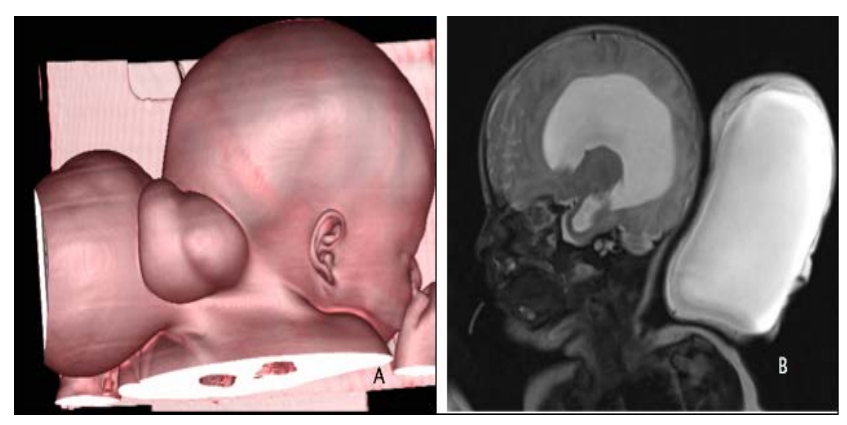

Resim 2. A. Beyin BT'de occipitoservikal yerleşimli ensefaloselin üç boyutlu görüntüsü. B. Occipitoservikal yerleşimli ensefalosel kesesi ve hidrosefali varlığı.

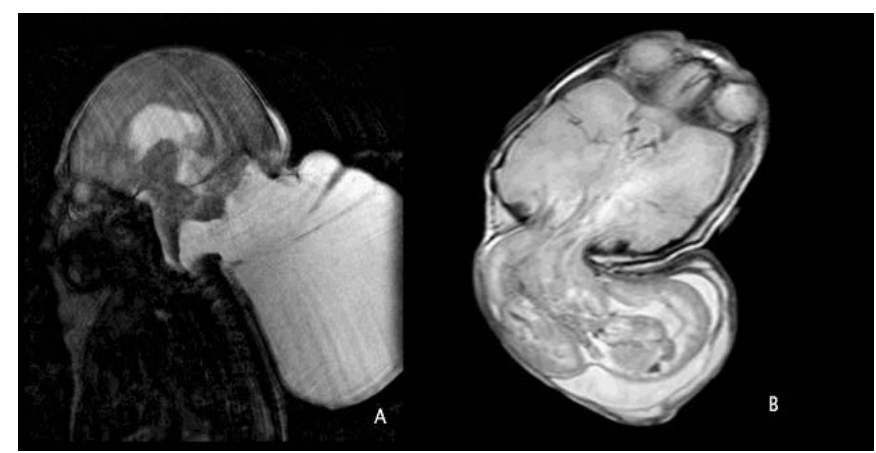

Resim 3. A. BOS içerikli dev ensefalosel B. Displastik beyin dokusu içeren dev ensefalosel

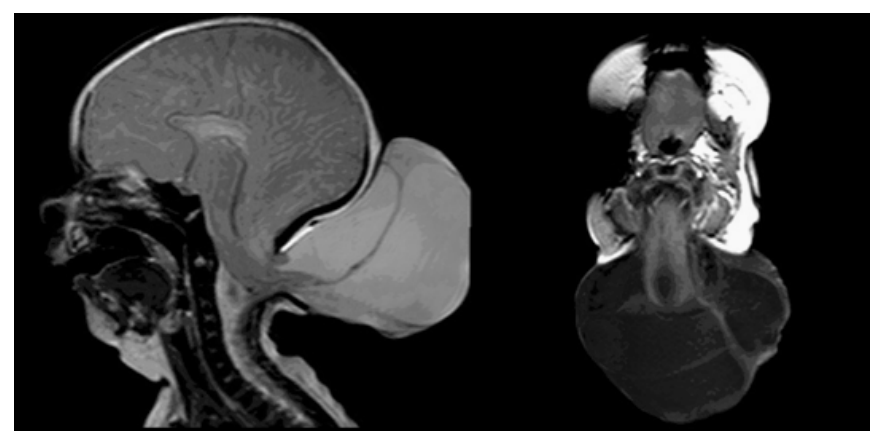

Resim 4. Normal nöral dokunun kese içerisine herniye olduğu ensefalosel olgusu

Hastaların \%21,9'unda ek anomali mevcuttu. Hastaların ikisinde birden fazla ek anomali mevcuttu. Santral sinir sistemi anomalisi eşlik eden üç hasta vardı (spinal anomali). Kardiyak anomali eşlik eden üç hasta, GIS anomalisi eşlik eden bir hasta mevcuttu. Hastalardan birinde Meckel Gruber Sendromu mevcuttu.

Hastaların \%65,6'sında doğumda veya bir yıllık takip süresinde şant takılmasını gerektirecek ventriküler dilatasyon saptanmıştır. Kız bebeklerin \%60's, erkek bebeklerin \%75'ine şant takılmış olup istatistiksel olarak anlamlı bulunmamıştır ( $\mathrm{p}=0.319)$. Şant takılan hastalarda kese boyutu ortalaması $84.5 \pm 25.0$ $\mathrm{cm}^{2}$ iken, takılmayanlarda $69.4 \pm 35.0 \mathrm{~cm}^{2}$ olarak saptanmış olup istatistiksel olarak anlamlı değildir ( $\mathrm{p}=0.720)$.

En küçük yaştaki anne 19 yaşında olup en büyügü 36 yaşında idi. Anne yaş ortalaması 27.1 \pm 4.3'tü. Anne yaşları değerlendirildiğinde annelerin 31.3'ü 19-25 yaş aralığında, \%62,5'i 25-34 yaş aralığında, \%6,2' si 34 yaşından büyük olduğu görülmüştür. 'Dev ensefaloseller'de anne yaş ortalaması daha büyük saptansa da (28.6/26.8) istatistiksel olarak anlamlı bulunmamıştır ( $\mathrm{p}=0.414$ ) (Tablo 1).

$\% 12,5$ (4) oranında ebeveynler arasında akraba evliliği saptanmıştır. 'Dev ensefaloseller'in \%20'sinde ebeveynler arasında akraba evliliği mevcuttu (Tablo 1).

Tablo I: Dev ve küçük ensefalosellerin karşılaştırılması

\begin{tabular}{|l|l|l|l|}
\hline & $\begin{array}{l}\text { Küçük } \\
\text { Ensefalosel } \\
(\mathrm{n}=27)\end{array}$ & $\begin{array}{l}\text { Dev } \\
\text { Ensefalosel } \\
(\mathrm{n}=5)\end{array}$ & \\
\hline Cinsiyet (K/E) & $\% 62,5 / 37.5$ & $\% 40 / 60$ & $p=0.001$ \\
\hline Defisit (+) & $\% 7,4$ & $\% 40$ & $p=0.042$ \\
\hline Hidrosefali & $\% 66,6$ & $\% 60$ & $\mathrm{p}=0.773$ \\
\hline Anne yaş & 26,8 & 28.6 & $\mathrm{p}=0.414$ \\
(Ort.) & $\% 12,5$ & $\% 20$ & $\mathrm{p}=0.769$ \\
\hline Akraba evliliği & $\%$ & & \\
\hline
\end{tabular}

Hastaların \%93,75'i taburcu edilmiştir. 2 hastada $(\% 6,25)$ ise peroperatif dönemde mortalite gelişmiş olup mortalite ile sonuçlanan hastaların ikisi de kız bebek olup ikisinde de ek kardiyak anomali mevcuttu. 'Dev ensefalosel'lerin \%20'si peroperatif dönemde mortalite ile sonuçlanırken diğer grupta \%3,7 oranında mortalite saptanmıştır.

Postoperatif erken dönemde gelișen 
komplikasyonlar değerlendirildiğinde iki hastada $(\% 6,25)$ yara yerinden beyin omurilik sıvısı (BOS) sızıntısı gelişti, şant taktıktan sonra sızıntı durdu. Yara yerinde cilt defekti gelişen bir hasta $(\% 3,1)$ yara bakımı ile revizyon cerrahisi gerekmeden iyilești.

\section{Anestezi;}

Bütün olgularda oda ısısının yenidoğan için yeterli olması, uygun teknik ekipman, pediatrik tecrübesi olan anestezi uzmanı, olası kan kaybı ihtimaline karşı uygun koşullarda saklanmış eritrosit süspansiyonu hazırlığı, ek anomaliye yönelik preoperatif süreçte tetkik ve planlama yapıldl.

Özellikle büyük kesesi olan ensefallosellerde entubasyon pozisyon nedeniyle zor olabilmektedir. Bu nedenle büyük kesesi olan olgularda video laringoskop hazır bulunduruldu. Küçük kesesi olan olgularda, baş altına yerleştirilen ortası delikli olan silikon baş yastıkları genellikle yeterli olurken daha büyük kesesi olan olgularda hasta lateral pozisyondaki iken sedasyona başlandıktan sonra, kese cerrahi ekip tarafından kontrol edilerek bebeklere pozisyon verildi. Bazı hastalarda lateral dekübit pozisyonda entübasyon yapılırken bazı hastalarda baş ve gövde masadan yukarıda, kese cerrah kontrolünde iken entubasyon işlemi gerçekleştirildi.

\section{Cerrahi teknik;}

Hastalar prone pozisyonda, uygun sterilizasyon sonrası kese çevresi dönülerek opere edildi. Sadece sıvı içerikli ve dural tabanı dar olanlar tek bırakılana kadar çevre dokulardan sıyrılarak kese tabanı bağlandıktan sonra eksize edildi. Küçük ensefalosellerde ve/veya kese içerisinde belirgin nöral eleman olmayan hastalarda primer eksizyon yeterli oldu. Hiçbirinde cilt flebi ihtiyacı olmadı.

'Dev ensefaloseller'den kese içerisinde nöral eleman olanlarda ise; beyin sapı olan hastalarda beyin sapı korundu ancak nöral dokular rezeke edildi. İki olgu dışındaki olguların tamamında kese içerisindeki nöral dokular displastikti. İki olguda ise kese içerisinde ventrikülü de içeren normal beyin dokusu mevcuttu. Bu olgularda occipital lobda kısmen rezeksiyon uygulanmak zorunda kalındı. Beyin sapı korundu. Occipital lob rezeksiyonu sonrası ventriküle ulaşılan ve kese içerisine uzanan koroid pleksusun gözlendiği bu iki olguda koroid pleksus kısmen koagule edilerek hidrosefali riski azaltılmaya çalışıldı.

\section{TARTIŞMA}

Ensefalosel ile doğan bir bebeğin prognozu lezyon lokalizasyonu, boyutu, kese içeriği ve eşlik eden anomali ile yakından iliş̧ilidir ${ }^{10}$. 'Dev ensefaloseller' ise oldukça nadir görülen, anestezi ve cerrahi sırasında pozisyon verme, kese içeriği, mikrosefali, aşırı BOS drenajına bağlı komplikasyonlar, hipotermi, kan kaybı gibi nedenlerle yönetimi peroperatif süreçte oldukça zor olan bir gruptur ${ }^{11}$. Bu çalışma ile ensefalosel nedeniyle opere edilen hastaların özellikleri ile birlikte peroperatif süreçteki zorluklar değerlendirilmiştir.

Bot ve arkadaşlarının 14 'dev ensefalosel'in incelendiği çalışmada hastaların \%71,4'ü kız çocuktu9. Mahapatra'nın yaptığı 'dev ensefalosel' olgularının incelendiği çalışmada ise \%64,2 oranında erkek cinsiyet baskınlığı olduğu belirtilmiştir ${ }^{11}$. Bizim çalışmamızda tüm ensefaloseller incelendiğinde kız çocuk oranının (62.5) yüksek olduğu, 'dev ensefaloseli' olanlar da ise \%60'ının erkek çocuk olduğu görülmüştür.

Yucetas ve Ucler'in 32 ensefalosel olgusunu inceledikleri çalışmada hastaların hiçbirinde preoperatif dönemde ekstremitelerde nörolojik defisit olmadığını belirtmişlerdir. Ancak çalışmada 'dev ensefaloseli' olan olgu olup olmadığı belirtilmemiş, en büyük kese boyutu $15 \times 17 \mathrm{~cm}$ olarak belirtilmiş, 3 olguda ek olarak myeloşizis olduğunu belirtseler de defisit olmadığını ifade etmişlerdir ${ }^{1}$. Bizim olgularımızda ise $\% 6,25$ 'ine eşlik eden ek spinal 
anomali (meningomyelosel) olup bu hastalar paraplejikti. Aynı zamanda kese içerisinde displastik olmayan nöral eleman içeren iki olgu de preoperatif dönemde quadriparetikti. Meningomyeloseli olan olgular normal boyutlu keselere sahip ensefalosellerdenken quadriparetik olanlar 'dev ensefaloselli' olgulardandı. Bu durum göz önüne alındığında kese boyutunun ek spinal anomali ile ilişkili olmadığı ancak kese boyutu büyüdükçe normal parankim içerme riskinin arttığ bunun da defisit riskini arttırdığı kanaati oluşmuştur.

Ensefalosel olgularına \%36-60 oranında intra/ekstrakranial ek anomali eşlik edebileceği bilinmektedir ${ }^{12}$. Çalışmamızda \%21,9 oranında ek anomali saptanmış olup ortalamadan düşük olmasının sebebinin intrakranial anomalilerin çalışmamıza dahil edilmemiş olduğu düşünüldü. Spinal ve kardiyak anomalilerin sık eşlik ettiği görülmüştür.

Da Silva ve arkadaşlarının yaptığı çalışmada ensefalosel kesesi içerisinde nöral eleman bulunan olgu oranının \%67 olduğunu belirtmişlerdir. Hastalarının \%24'ünde hidrosefali geliştiğini ve hidrosefali gelişiminin kese içerisinde nöral doku varlığl, kranial ek anomali varlığı ve kese boyutunun $2 \mathrm{~cm}$ 'den büyük olması ile ilişkili olduğunu belirtmişlerdir ${ }^{13}$. Çalışmamızda ise olguların \%53,1'inde kese içerisinde nöral doku bulunurken, hastaların \%65,6'sında bir yıllık takiplerde hidrosefali nedeniyle şant takılma ihtiyacı olmuştur. Kese boyutu ile hidrosefalinin ilişkisi istatistiksel olarak anlamlı bulunamamış olsa da olgularımızın neredeyse tamamında $(\% 90,6)$ kese boyutunun $2 \mathrm{~cm}$ üstünde olduğu görülmüştür. Bu da Da Silva ve arkadaşlarının yaptığı çalışmaya göre hidrosefali gelişme oranının yüksek olmasını açıklar. Ayrıca çalışmamızda kese boyutu $2 \mathrm{~cm}$ ve altında olan üç olgunun hiçbirinde hidrosefali gelişmemiştir. Dev ensefaloseli olan iki olguda ise koroid pleksus koagule edilmiş, bu iki olgunun uzun dönem takiplerinde hidrosefali gelişmemiş, bu durumların istatiksel sonuçları etkilediği düşünülmüştür.

32 ensefalosel olgusunun değerlendirildiği bir çalışmada anne yaş ortalaması 30 bulunmuş ve $\% 56$ oranında akraba evliliği saptanmıștır ${ }^{1}$. Bot ve arkadaşlarının 'dev ensefaloseller' ile ilgili çalışmasında anne yaş ortalaması 20.3 olarak bulunurmuştur'. Çalışmamızda ise 'dev ensefaloseller'de diğerlerine göre anne yaş ortalaması ve akraba evlilik oranı daha yüksek olsa da istatistiksel olarak anlamlı bulunmamıștır.

Ensefalosel olgularında yaşam süresini etkileyen en önemli faktörler kese içerisinde nöral eleman varlığıdır ${ }^{14,15}$ ancak yaşam kalitesini etkileyen, nöral gelişim üzerine en etkili faktör ise hidrosefali olup olmadığıdır ${ }^{13}$. $\mathrm{Bu}$ durum göz önüne alındığında 'dev ensefaloseller'in yaşam kalitesinden çok içeriğindeki nöral doku nedeniyle yaşam süresini etkilediği kanaati oluşmuştur.

Diğer çalışmalarda ve çalışmamızda 'dev ensefalosel' gelişimini etkileyen faktörler tespit edilememiştir ${ }^{1,9}$. Ancak 'dev ensefaloseller'de preoperatif hazırlık ve intraoperatif yaklaşımı ile diğer ensefalosellerden ayrıldığı aşikardır. Zor entubasyona neden olan anatomik ve konjenital bir patolojidir ${ }^{16}$. Hastaya anestezi sırasında entubasyon için pozisyon verme güçlüğü, hipotermi, kan kaybı riski, nörolojik defisit gelişme olasılığı, yüksek BOS volümü nedeniyle elektrolit imbalansı, hızlı BOS drenajına bağlı bradikardi gibi nedenlerle preoperatif dönemde hazırlığının iyi yapılması gereken olgulardır ${ }^{17,18}$. Anestezi için lateralsupin pozisyonda entubasyon ${ }^{19}$, BOS boşaltma ${ }^{20}$, keseyi masadan aşağı sarkıtma ${ }^{21}$ gibi teknikler kullanılabilmektedir. Kliniğimizde operasyon öncesinde gelişebilecek benzeri komplikasyon ihtimalleri nedeniyle önceden hazırlık yapılmaktadır. Hastalara uygun pozisyon cerrah kontrolünde verildiğinden kese rüptürü gözlenmemiş ve cerrahi öncesinde entubasyon için BOS drenajı 
ihtiyacı olmamıştır. Küçük keselerde supin pozisyonda entubasyon yapılırken büyük keselerde lateral pozisyon ya da hastanın baş ve gövde kaldırılarak kesenin cerrahi ekip kontrolünde olduğu teknikler kullanılmıştır. Hastalarda cerrahi süresinde kan transfüzyonu ihtiyacı olmamıştır. Cerrahi sırasında hipotermiden korunmak için yenidoğana uygun ısıtma battaniyeleri kullanırken cerrahi sonrası anesteziden uyandırma döneminde üflemeli hava ısıtma cihazları da eklenmektedir.

Cerrahi planlanma kesenin rüptüre olmadığı durumlarda elektif planlama yapmak gerekir. Preoperatif dönemde yeterli radyolojik görüntülemelerle ve gerekirse radyoloji uzmanı ile birlikte değerlendirilerek yapılmalıdır. Gerekirse aşamalı ve geç cerrahi uygulanarak displastik olmayan nöral dokunun korunması sağlanmalıdır22. Hastalarımızda cerrahi planlama yapılırken bu durumlar göz önünde bulundurularak gereken hastalarda önce ventriküloperitoneal şant takıldı. Sonra kese eksizyonu planlandı. Cerrahi sırasında yüksek volümlü BOS içeren keselerde BOS drenajı kontrollü bir şekilde sağlanmaktadır. Dural tabanı dar olan olgularda kese çevresi dönülerek dural taban primer kapatılacak duruma gelene kadar BOS drenajı yapılmadan işleme devam edilir. Preoperatif görüntülemede kese içerisinde nöral doku saptananlarda ise kesede kontrollü drenaj sağlanarak displastik beyin dokusu bipolar yardımı ile koagule edilerek eksize edilir. Ancak beyin sapının korunduğundan ve travmatize edilmeden eksizyon sağlandığından emin olunarak işleme devam edilir. Hastalarımızda peroperatif mortalite gözlenmemiştir. Ancak iki hastamızda ek anomalilerine sekonder cerrahiden sonraki bir ay içerisinde mortalite gelişmiştir.

Tüm hastalar postoperatif dönemde yenidoğan yoğun bakımda kardiyovasküler komplikasyonlar, sıvı-elektrolit imbalansı, kan kaybına bağlı hemodinamik bozukluklar açısından yakın takip edilmektedir.

\section{SONUÇ}

Ensefaloseller peroperatif süreci multidisipliner bir anlayışla iyi yönetilmesi gereken bir hasta grubudur. Morbidite ve mortalite riski ancak multidisipliner bir yaklaşımla azaltılabilir.

Her ne kadar 'dev ensefaloseller'in postoperatif süreci diğer ensefalosellerle aynı olsa da preoperatif hazırlığın dikkatli yapılması, anestezi ve cerrahi ekibin koordine çalışması diğer ensefalosellere göre yüksek olan peroperatif komplikasyon riskini azaltacaktır.

Etik Kurul Kararı: Çalışma için Sağlık Bilimleri Üniversitesi Gazi Yaşargil Eğitim Araştırma Hastanesi girișimsel olmayan klinik araștırmalar etik kurulundan 14.02.2020 tarih 402 sayı numarası ile onay alınmıștır. Tüm hastalar için bilgilendirilmiş yazılı onam alınarak Helsinki Deklarasyonu prensiplerine uyulmuştur.

Çıkar Çatışması Beyanı: Yazarlar çıkar çatışması olmadığını bildirmişlerdir.

Finansal Destek: Bu çalışma her hangi bir fon tarafından desteklenmemiştir.

Declaration of Conflicting Interests: The authors declare that they have no conflict of interest.

Financial Disclosure: No financial support was received.

\section{KAYNAKLAR}

1. Yucetas SC, Uçler N. A Retrospective Analysis of Neonatal Encephalocele Predisposing Factors and Outcomes. Pediatr Neurosurg. 2017; 52: 73-6. doi: 10.1159/000452805.

2. Satyarthee GD, Mahapatra AK. Craniofacial surgery for leaking encephalocele in a neonate. J Clin Neurosci. 2002; 9: 593-5.

3. Mahapatra AK, Dev EJ, Krishnan A, Sharma RR. Craniofacial surgery for leaking encephalocele in a newborn. Childs Nerv Syst. 2001 Oct; 17(10): 626-8. doi: $10.1007 / \mathrm{s} 003810100483$. 
4. Sirikci A, Bayazit YA, Bayram M. The Chiari III malformation: an unusual and asymptomatic variant in an 11-year old child. Eur J Radiol. 2001; 39: 147-50.

5. Raja RA, Qureshi AA, Memon AR, Ali H, Dev V. Pattern of encephaloceles: A case series. J Ayub Med Coll Abbottabad. 2008; 20: 125-8.

6. Kılıç K. Kraniyal Meningosel, Ensefalosel. Türk Nöroşirürji Dergisi. 2013; 23: 250-4.

7. Ağaçayak E, Turgur A, Yaman Tunç S, Özler A. Meckel-Gruber Syndrome: Report of nine cases and a literature review. Dicle Med J. 2013; 40: 645-50 doi:10.5798/dicletip.2013.04.0349.

8. Aydin Ozturk P, Asena M, Katar S, Ozturk U. Meckel-Gruber Syndrome: A Case Who Lived for 5 Months. Pediatr Neurosurg. 2019; 54: 277-80. doi: $10.1159 / 000500766$.

9. Bot GM, Ismail NJ, Mahmud MR, et al. Giant Encephalocele in Sokoto, Nigeria: A 5-Year Review of Operated Cases. World Neurosurg. 2020; 139: 516. https://doi.org/10.1016/j.wneu.2020.03.061.

10. Andarabi Y, Nejat F, El-Khashab M. Progressive skin necrosis of a huge occipital encephalocele. Indian J Plast Surg. 2008; 41: 82-4.

11. Mahapatra AK. Giant Encephalocele: A Study of 14 Patients. Pediatr Neurosurg. 2011; 47: 406-11. DOI: $10.1159 / 000338895$.

12. Liao SL, Tsai PY, Cheng YC, et al. Prenatal diagnosis of fetal encephalocele using threedimensional ultrasound. J Med Ultrasound. 2012; 20: $150-4$.

13. Da Silva SL, Jeelani Y, Dang H, Krieger MD, McComb JG. Risk factors for hydrocephalus and neurological deficit in children born with an encephalocele. J Neurosurg Pediatr. 2015; 15: 3928.

14. Siffel C, Wong LY, Olney RS, Correa A. Survival of infants diagnosed with encephalocele in Atlanta, 1979-98. Paediatr Perinat Epidemiol. 2003; 17: 408. doi: 10.1046/j.1365-3016.2003.00471.x.

15. Rehman L, Farooq G, Bukhari I. Neurosurgical Interventions for Occipital Encephalocele. Asian J Neurosurg. 2018; 13: 233-7.

16. Akelma H, Salık F, Bıçak M, et al. Combination of Spinal Anesthesia and UsgGuided Low-Dose Bilateral Infraclavicular Block in a Patient with Difficult Airway: A Rare Case Report. Adv Case Stud. 2019; 2: 1-4.

17. Uzun Ş, Akaycan B, Işıkay I, Aypar Ü. Dev Ensefaloselli Olguda Anestezi Yönetimi. Turkiye Klinikleri J Case Rep. 2015; 23: 105-9.

18. Mahajan C, Rath GP, Bithal PK, Mahapatra AK. Perioperative management of children with giant encephalocele: A clinical report of 29 cases. J Neurosurg Anesthesiol. 2017; 29: 322-9.

19. Creighton RE, Relton JES, Meridy HW. Anaesthesia for occipital encephalocoele. Can Anaesth Soc J. 1974; 21: 403-6.

20. Vasudevan A, Kundra P, Priya G, Nagalakshmi P. Giant occipital encephalocele: a new paradigm. Pediatric Anesthesia. 2012; 22: 581-610. doi:10.1111/j.1460-9592.2012.03849.x

21. Quezado Z, Finkel JC. Airway management in neonates with occipital encephalocele: easydoes it. Anesth Analg. 2008; 107: 1446.

22. Bozinov O, Tirakotai W, Sure U, Bertalanffy H. Surgical closure and reconstruction of a large occipital encephalocele without parenchymal excision. Childs Nerv Syst. 2005; 21: 144-7. 